\title{
Reflections on Freedom of Thought and Opinion Contained in the Fourth Principle of Pancasila
}

\author{
Theodorus Christian Gunawan \\ Faculty of Philosophy, Widya Mandala Catholic University, Surabaya, Indonesia
}

\section{Email address:}

phil.theodorus.c.19@ukwms.ac.id

\section{To cite this article:}

Theodorus Christian Gunawan. Reflections on Freedom of Thought and Opinion Contained in the Fourth Principle of Pancasila. Journal of Political Science and International Relations. Vol. 4, No. 3, 2021, pp. 78-82. doi: 10.11648/j.jpsir.20210403.12

Received: May 26, 2021; Accepted: July 30, 2021; Published: August 18, 2021

\begin{abstract}
One of the human rights is freedom of thought and opinion. This right or freedom is contained in various laws. This freedom of thought and opinion is of course very necessary, especially in an era where democracy seems to be the most widely embraced in various countries. This is because the democratic system emphasizes the greatest possible sovereignty on the people or citizens. However, there are problems related to freedom of thought and opinion. Furthermore, the writer who comes from Indonesia also wants to introduce a state basis that is owned by Indonesia. In Indonesia there is a state foundation called Pancasila. Pancasila itself is a state foundation which is the hallmark of the Indonesian nation. This is because Pancasila is indeed suitable and in accordance with the soul, personality, and ideals of the Indonesian state and nation. The Fourth Principle contains a basis that supports the freedom of thought and opinion for all Indonesian people. However, this freedom of thought and opinion is of course limited by law; this is mainly done to anticipate if there is an abuse of freedom of thought and opinion that deviates from the common goal, namely the common good. From that reason, there is no freedom of human rights, namely freedom of thought and opinion that is purely absolute and unlimited. This limitation is needed especially to ensure that the common good can be realized properly.
\end{abstract}

Keywords: Freedom of Thought, Freedom of Opinion, Boundaries, Pancasila, The Fourth Principle, Mutual Good

\section{Introduction}

Humans as free creatures can certainly control themselves over their consciousness, will, and freedom. Of course, freedom is also contained in thinking and opinion. This kind of freedom can be seen in a system of government that is democratic in character. The democratic government system places the greatest possible sovereignty in society. Thus, freedom of thought and opinion is very much heeded and respected.

However, what about countries that do not implement democracy? Do not such countries place less emphasis on individual freedom of thought or opinion? If so, is freedom of thought and opinion absolutely necessary? Are there any limitations required? All these questions are often asked to continue to reflect on freedom of thought and opinion.

One of the countries in the world that has a state basis regarding freedom of thought and opinion is Indonesia. The Indonesian state has a state foundation called Pancasila. The fourth principle contains values that reflect freedom of thought and opinion. The author wants to use the basis of the Indonesian state because the author wants to explore the wealth of values of freedom of thought and opinion contained in the Fourth Principle of Pancasila; besides that, because the author comes from the country of Indonesia, this is also an effort to love the Indonesian people more.

This paper intends to see and reflect more deeply on the freedom of thought and opinion contained in Pancasila, specifically the fourth principle. Of course, there is a lot of discussion regarding this theme. The author will also use several reliable sources to enrich discussion and reflection on freedom of thought and opinion. The purpose of this paper is to further gain a deeper understanding of the freedom of thought and opinion contained in Pancasila, specifically the Fourth Principles. Thus, this paper is an attempt to reflect continuously. 


\section{Freedom of Thought and Opinion}

\subsection{The Essence of Freedom of Thought and Opinion}

Everyone has the freedom to think and have an opinion, because this is one of the human rights [1]. Therefore freedom of thought and opinion is a common thing in a human being. This kind of human right cannot just be taken away by other people. For example, in the country of Indonesia, this freedom of thought and opinion is regulated in the 1945 Constitution of the Republic of Indonesia, more precisely in the 1945 Constitution Article 28 E paragraph (3).

This freedom of thought and opinion is something that is regulated in a law that exists in a democratic country [2]. This democratic political system allows freedom of thought and opinion. This also means that the democratic system is very open with in-depth discussions and discussions related to efforts to achieve the common good. In order to achieve this goal, a regulation is made that can guarantee the implementation of freedom of thought and opinion.

Thus, it appears that freedom of thought and opinion is a solid foundation for the creation of a free and democratic society; especially for the sake of the sustainability of a democratic system that allows public participation in every policy-making process [3]. Therefore, the authors see that the democratic system supports the notion that humans naturally have human rights in the form of freedom of thought and opinion. This is the essence of freedom of thought and opinion, especially since it is a natural right.

\subsection{Reasons for the Need for Freedom of Thought and Opinion}

Jenny Teichman sees that there are five reasons for the need to respect freedom of thought and opinion, among others, because of: power, wealth, happiness, human needs, and knowledge and truth [4]. The first reason is power because there is an assumption that the existence of freedom of thought and opinion can make a country have strong power. However, this can immediately be debated due to the fact that there are countries that do not exercise freedom of thought and opinion in their countries, but are still recognized as strong countries $[5]$.

The second reason is because there is an assumption that freedom of thought and opinion can increase the economic strength of a country. The third reason is happiness. This reason is based on the assumption that freedom of thought and opinion can help someone to achieve happiness in life. The fourth reason is that freedom of thought and opinion is a human need. This is based on the fact that if this kind of freedom is limited, then humans will only be reduced to an inhuman level [6].

The fifth reason is that freedom of thought and opinion helps develop human knowledge and helps uncover truths that should be revealed [7]. Revealing the facts of truth is an effort to fight for justice, because nothing is kept secret; hopefully all truth can be revealed for the common good.

In general, the authors note that these five reasons are evident in certain countries only. The state system that is most vigorous and suitable for implementing freedom of thought and opinion is democracy. Thus, these reasons are likely to become the basis for the existence of freedom of thought and opinion in a country characterized by democracy.

\subsection{Issues Related to Freedom of Thought and Opinion}

Problems always arise in various aspects of human life, including in terms of freedom of thought and opinion. One of the problems related to freedom of thought and opinion occurs in the issue of pornography. In different parts of the world pornography laws vary widely. There are countries that legalize pornography and there are also those that strictly prohibit the industry. This is also due to the assumption that freedom of thought and opinion can be applied freely; even when it comes to pornography.

The law relating to pornography has always been controversial. This is due to failure in its application. The fact is that there is often a mismatch between the purpose of the law and its application in the field [8]. From the problems related to pornography, then the question arises, is there freedom of thought and opinion as freely as possible; even in terms of showing off the body. From this one issue alone, it can be seen that there must be limitations related to freedom of thought and opinion.

Furthermore, the next problem is, for example, related to freedom in social media in this digital era. For example, in Indonesia there is a law that regulates freedom in this digital world. This law in Indonesia is called the ITE Law. The existence of the ITE Law is a very clear sign or warning for internet and social media users to always be careful when using, sharing, and taking information that is very personal in nature [9].

\section{Understanding of Pancasila: Specially the Fourth Principle}

Pancasila is a foundation of the Indonesian state, the preparation of which has gone through stages that have been discussed together; it means that Pancasila is not something that suddenly appears, but has already undergone the stages of "conception", "formulation" and "ratification" [10]. In historical terms, Pancasila has indeed gone through various formulation processes; and even historically Pancasila is indeed in accordance with the spirit of the Indonesian nation itself. Apart from that, Pancasila is also very visible to Indonesian rationality, from its various aspects. Therefore, Pancasila as a view of life, ideology, unifier, as well as a dynamic guide, always has its actuality in order to achieve the goals of the Indonesian nation [11]. The contents of Pancasila include: 1) Supreme Lordship, 2) Just and civilized humanity, 3) Indonesian Unity, 4) Democracy led by wisdom in deliberation / representation, 5) Social justice for all Indonesian people.

The fourth principle of Pancasila emphasizes the sovereignty of the people in the spirit of deliberation in 
accordance with the wisdom of wisdom. This fourth principle strengthens the vision of democracy in Indonesia, which really emphasizes efforts to freedom of thought and opinion within the framework of deliberation to reach consensus, so as to achieve the welfare of Indonesian citizens based on a strong and equal economy. From the fourth principle, one can find basic ideas about freedom of thought and opinion. This means that freedom of thought and opinion has been regulated on the basis of the Indonesian state.

Therefore, it is increasingly clear that Pancasila, in particular the Fourth Principle, does contain the values of freedom of thought and opinion, which in fact have become the basic right of every citizen. Not only that, the idea of democracy in Indonesia is indeed in line with Indonesia's economic and political vision. Thus, Indonesian democracy is also a democracy that tries to harmonize political democracy and economic democracy, where the vision of both is for the common welfare.

\section{Various Forms of Freedom of Thought and Opinion and Their Relation to the Fourth Principle of Pancasila}

After taking a glimpse at the basics of freedom of thought and opinion and the Fourth Principle of Pancasila, the authors see that these two things are interrelated. These two things have a significant influence on life together in Indonesia, in particular political and social life together. Both the Fourth Principle and freedom of thought and opinion are interrelated and important for the survival of the Indonesian nation. Therefore, in order to make both of them more concrete and able to solve some daily problems, the writer tries to make them concrete by applying them to more specific things. This is of course aimed at grounding Pancasila specifically the Fourth Principles, and trying to provide a little aspiration that can be an effort to resolve problems that occur in freedom of thought and opinion.

First of all, the author invites to see about freedom of thought and opinion in digital media. As we all know, digital media seems to be fundamental in this era. People today seem inseparable from the use of digital media. This is because electronic media and social media become a stage or a place for various kinds of information to flow as well as a place for various kinds of people to think and express opinions (expression) [12]. In line with the Fourth Pancasila Principles, digital media is very likely to become a means of implementing deliberations to reach consensus. Every individual is allowed to convey their aspirations through digital media; such as Instagram, Facebook, Twitter and Youtube.

Next, the author also invites to see the freedom of thought and opinion in this democratic era, especially in Indonesia. Democracy that is applied in Indonesia is not a democracy that is stuck in Indonesia just like that. Indonesian democracy truly reflects the personality, soul and aspirations of the Indonesian people; therefore, it is not just a technical tool to perpetuate a government system [13]. This means that the democracy that is constantly being pursued in this country is a genuine democracy and in accordance with the conditions of the Indonesian nation.

Pluralism in Indonesia requires a sovereignty in the hands of the people. This sovereignty is of course aimed at achieving the common good. Therefore, a democratic system makes it very possible for every citizen to be free to think and have an opinion. From this, it can also be seen that the people's freedom to aspire is aimed at shaping the character of the people who are wise in issuing opinions that are beneficial to the common good in the country [14]. So, these efforts are very much in accordance with the Fourth Principle that the Indonesian nation has.

Freedom of thought and opinion can also be found in daily encounters in the environment where each person lives. Indonesia is a country with a very strong culture of togetherness. Each person in the neighborhood seems to care for each other. From that reason, the Fourth Principle of Pancasila and freedom of thought and opinion are certainly very much in line with the daily problems of the Indonesian people. In their daily lives, the Indonesian people need to consult to reach a consensus, and this presupposes the existence of freedom of thought and opinion. Hence, the continuity between the Fourth Principle and freedom of thought and opinion becomes ever clearer.

Furthermore, it is important to look at freedom of thought and opinion in academia. Academic freedom in fact seeks to protect the right to acquire and develop knowledge. The effort to continue to acquire knowledge is not an activity that is elitist in character, but rather an important exercise for implementing democracy and aims to educate students and academics to contribute to achieving a common good [15].

Therefore, freedom in the academic world actually really helps the application of freedom of thought and expression in academics. Those who cultivate themselves in academic institutions also try to exercise their freedom of thought and opinion. This is of course also in line with the Fourth Principle, because it seeks to implement deliberation to reach consensus, especially in the academic world. Therefore, freedom of thought and opinion in academia must also be upheld.

After seeing the various kinds of freedom of thought and opinion that are found in various aspects, now the author also wants to glimpse the limitations of freedom of thought and opinion. It is true that freedom of thought and opinion is a human right that should be respected and respected. However, a limitation is also needed, so that there is no abuse of freedom. This limitation is of course aimed at achieving a common good. In the International Convenant on Civil and Political Rights or ICCPR, it is explained that it is very possible for a limitation or reduction to various types of human rights, and this of course remains conditional and situational [16]. From this, it is clear that freedom of thought and opinion, which is a human right, is of course also limited when it starts to worry about the freedom of others.

Thus, there is no such thing as being free as freely as possible. Freedom of thought and opinion is still limited as far 
as it can achieve what is the common goal in a society. Therefore, human rights in terms of freedom of thought and opinion are never absolute or unlimited, because there are limitations that must be carefully considered [17].

From the various kinds of freedom of thought and expression as well as these limitations, it is likely that a deeper and comprehensive understanding of freedom of thought and opinion is obtained; as well as its relation to the Fourth Pancasila Principle. These various kinds of understanding can certainly enrich people's understanding. Thus, freedom of thought and opinion is always a human right, and this right is also contained in the Fourth Pancasila Principle.

\section{Conclusion and Recommendations}

Through all this discussion, the author can conclude that indeed freedom of thought and opinion is a human right that must be respected. Freedom is contained in a variety of things. In addition, Pancasila, which is the foundation of the Indonesian state, also contains elements of freedom of thought and opinion in it, especially in the Fourth Principles.

In this section, the author will also provide some useful recommendations for ensuring a freedom of thought and opinion in general, and in particular in Indonesia, which is the country of origin of the author. First, the author recommends the government to always ensure the continuity of freedom of thought and opinion. Silencing people's voices is a violation of human rights, specifically the right or freedom of thought and opinion. Second, freedom of thought and opinion should be implemented in a country with a democratic system. The democratic political system is the most widely implemented system today, and it is a system that strongly supports the implementation of freedom of thought and opinion. The author recommends that every democratic country realizes how important freedom of thought and opinion is as a human right that is most worthy of respect in common life, especially for countries with democratic political systems. Third, the author also recommends that the freedom of thought and opinion be regulated in a law that favors the common good. This law is needed so that freedom is not used haphazardly or carelessly. Freedom of thought and opinion cannot be exercised freely, but there needs to be a limit as well; and its limitations must be discussed in each country, because each country has its own peculiarities and uniqueness. For this reason, the law that becomes a barrier is very important for the survival of democratic countries, especially those that are implementing freedom of thought and opinion.

Thus the three recommendations were made, and the three recommendations are still ideas that need to be made even more concrete, so that freedom of thought and opinion can become more real in society in general. Then the question is, who made it concrete? The answer from the author, of course, is that we are together as a society in general. Each individual has the right to contribute in concretizing freedom of thought and opinion. Why each personal? Because in society consists of people with various backgrounds, and that's where there is complementarity between each person.
However, freedom of thought and opinion, even though it is a human right, is still not something absolute or unlimited. This freedom is still limited by the regulations or laws in force in each country, in order to achieve a common good. This means that if there is an abuse of freedom of thought and opinion, such as hate speech characterized by racism or harassment, then the person who said the speech needs to be followed up legally because his actions disturb the common good in society. Thus, freedom of thought and opinion should remain focused on achieving the common good (bonum commune).

\section{References}

[1] Chandra S., Ujang, "Hakikat Hak Kebebasan Menyampaikan Pendapat di Muka Umum", in the Journal Komunikasi Hasil Pemikiran dan Penelitian, Vol. 3, No. 1 (April 2017), p. 45-56.

[2] Wijaya, Arif, "Kemerdekaan Berfikir dalam Hak Asasi Manusia dalam Islam", in the Journal Hukum dan Perundangan Islam, Vol. 3, No. 2 (Oktober 2013), p. 242-243.

[3] Marwandianto \& Hilmi Ardani Nasution, "Hak atas Kebebasan Berpendapat dan Berekspresi dalam Koridor Penerapan Pasal 310 dan 311 KUHP”, in the Journal HAM, Vol. 11, No. 1 (April 2020), p. 1-25.

[4] Teichman, Jenny, Etika Sosial, (judul asli: Social Ethics: A Student's Guide), diterjemahkan oleh A. Sudiarja, Yogyakarta: Kanisius, 1998, p. 152-155.

[5] Teichman, Jenny, Etika Sosial, (judul asli: Social Ethics: A Student's Guide), diterjemahkan oleh A. Sudiarja, Yogyakarta: Kanisius, 1998, p. 152-153.

[6] Teichman, Jenny, Etika Sosial, (judul asli: Social Ethics: A Student's Guide), diterjemahkan oleh A. Sudiarja, Yogyakarta: Kanisius, 1998, p. 154.

[7] Teichman, Jenny, Etika Sosial, (judul asli: Social Ethics: A Student's Guide), diterjemahkan oleh A. Sudiarja, Yogyakarta: Kanisius, 1998, p. 154-155.

[8] Wiratraman, R. Herlambang Perdana, "In Search of Constitutionality: Freedom of Expression and Indonesia's Anti-Pornography Law", in the Journal Yuridika, Vol. 27, No. 2 (Mei-Agustus 2012), p. 111-120.

[9] Arifin, Hadi Suprapto, Weny Widyowati, \& Taty Hernawaty, "Freedom of Expression di Media Sosial bagi Remaja secara Kreatif dan Bertanggung Jawab: Bagi Siswa SMA Al-Ma'soem Rancaekek dan SMA Muhammadiyah Pangandaran", in the Journal Pengabdian Kepada Masyarakat, Vol. 1, No. 5 (Oktober 2017), p. 332-337.

[10] Latif, Yudi, Negara Paripurna: Historisitas, Rasionalitas, dan Aktualitas Pancasila, Jakarta: Gramedia Pustaka Utama, 2021, p. 39-40.

[11] Latif, Yudi, Negara Paripurna: Historisitas, Rasionalitas, dan Aktualitas Pancasila, Jakarta: Gramedia Pustaka Utama, 2021, p. 41.

[12] Nasution, Latipah, "Hak Kebebasan dan Berekspresi Dalam Ruang Publik di Era Digital”, in the Journal 'Adalah: Buletin Hukum \& Keadilan, Vol. 4, No. 3 (2020), p. 37-48. 
[13] Latif, Yudi, Negara Paripurna: Historisitas, Rasionalitas, dan Aktualitas Pancasila, Jakarta: Gramedia Pustaka Utama, 2021, p. 475.

[14] Latif, Yudi, Negara Paripurna: Historisitas, Rasionalitas, dan Aktualitas Pancasila, Jakarta: Gramedia Pustaka Utama, 2021, p. 488.

[15] Scott, Joan W., "On Free Speech and Academic Freedom”, in the Journal AAUP Journal of Academic Freedom, Vol. 8 (2017), p. 1-10.
[16] Selian, Della Luysky \& Melina, Cairin, "Kebebasan Berekspresi di Era Demokrasi: Catatan Penegakan Hak Asasi Manusia", Dalam Jurnal Lex Scientia Law Review, Vol. 2, No. 2 (November 2018), hlm. 189-198. Wijaya, Arif, "Kemerdekaan Berfikir dalam Hak Asasi Manusia dalam Islam”, in the Journal Hukum dan Perundangan Islam, Vol. 3, No. 2 (Oktober 2013), p. 241-259.

[17] Emerick, Barrett, "The Limits of the Rights to Free Thought and Expression", in the Journal Kennedy Institute of Ethics Journal, (Juni 2021), p. 1-15. 